\title{
Analysis of Industrial Readiness 4.0 on Family Business
}

\section{Aryan Eka Prastya Nugraha ${ }^{\bowtie}$, Endang Wuryandini, Novika Wahyuhastuti, Oktaviani Adhi Suciptaningsih}

Department of Economic Education, Universitas PGRI Semarang, Indonesia

\begin{tabular}{l} 
Info Article \\
\hline History Article: \\
Received 6 December 2018 \\
Approved 24 May 2019 \\
Published March 2019 \\
\hline Keywords: \\
Industry 4.0; family business; \\
readiness.
\end{tabular}

\begin{abstract}
The purpose of this study is to provide a broader and deeper view of the readiness of family businesses in the face of the era of digital disruption 4.0. The sample used in this study was 93 family business units, with the method of Exploratory Factor Analysis (EFA) assisted by SMART-PLS. Based on the results of the hypothesis proposed that directly entrepreneurial and managerial competencies in the family business have a positive and significant effect on industry 4.0 readiness. Competence, especially in the implementation of managerial competencies for business owners. The managerial competency indicators is known as professional, social and personal. Indirectly, family businesses can implement business strategies that are by the characteristics of their business so they can adapt to rapidly changing conditions.Implementation of Information and Communication Technology (ICT) is considered to be crucial in facing the Industry 4.0.
\end{abstract}

\section{Analisis Kesiapan Indsutri 4.0 pada Bisnis Keluarga}

\begin{abstract}
Abstrak
Tujuan dari penelitian ini adalah untuk memberikan pandangan yang lebih luas dan lebih dalam tentang kesiapan bisnis keluarga dalam menghadapi era gangguan digital 4.0. Sampel yang digunakan dalam penelitian ini adalah 93 unit bisnis keluarga, dengan metode Exploratory Factor Analysis (EFA) yang dibantu oleh SMARTPLS. Berdasarkan hasil hipotesis yang diajukan bahwa secara langsung kompetensi kewirausahaan dan manajerial dalam bisnis keluarga memiliki pengaruh positif dan signifikan terhadap kesiapan industri 4.0. Kompetensi, terutama dalam penerapan kompetensi manajerial untuk pemilik bisnis. Indikator kompetensi manajerial dikenal sebagai profesional, sosial, dan pribadi. Secara tidak langsung, bisnis keluarga dapat menerapkan strategi bisnis yang sesuai dengan karakteristik bisnis mereka sehingga mereka dapat beradaptasi dengan kondisi yang berubah dengan cepat. Penerapan Teknologi Informasi dan Komunikasi (TIK) dianggap penting dalam menghadapi Industri 4.0.
\end{abstract}

JEL Classification: M2, M21

How to Cite: Nugraha, A. E. P., Wuryandini, E., Wahyuhastuti, N., \& Suciptaningsih, O. A. (2019). Analysis of Industrial Readiness 4.0 on Family Business. Jurnal Dinamika Manajemen, 10(1), 102-110. 


\section{INTRODUCTION}

Today many companies have developed digital channels to support sales and strategies in stages to deal with the onslaught of the increasingly rapid digital era. In the past two decades, purchasing through digital media has increased substantially, and technological advancements have made the buying and selling experience far more efficient, transparent and more comfortable. Current technological advancements require companies and stakeholders to rethink the way they do business and consider themselves partners to shape business models and innovations that utilise technology (Gjerding \& Kringelum, 2018).

This is undoubtedly a challenge for family businesses in the city of Semarang; the majority still use traditional models and adapt existing conditions. An organisation in all fields must always adapt to changing environmental or industrial conditions; it is essential for each organisation to gain a competitive advantage and maintain its current position about competitors (Bermúdez \& Juárez, 2017). Many conveniences can be felt if you can implement technology in it.

New concepts such as the Internet of Things, Industrial Internet, Cloud-based Manufacturing and Smart Manufacturing discuss digital production processes and are generally included in the concept of the Industrial Revolution 4.0 (Erol et al., 2016a). The concept is related to technological developments that continue to encourage automation. Eventhough automation and robotics are being part of the revolution in Industry 4.0, Internet of things still becoming the main role (Basl, 2016). The main purpose of Industry 4.0 is to reinforce and extend the longrange competitiveness of the corporation by increasing the flexibility and usefulness of production through information and intelligence.In a family business that can innovate it is not difficult to implement new digital-based technology (Gabriel and Pessl, 2016).

The last few years the view of the application of information technology strategy is a fun- ctional strategy that is aligned with the strategy of the business unit (Bharadwaj et al., 2013). Today's businesses must be able to compete globally and be able to adapt to rapid production to change demand. This can only be fulfilled by technological interference. Industry 4.0 is an approach that offers business and process integration, and the combination of all actors in the company's value chain (Rojko, 2017).

As the consumers, they tend to choose the most comfortable alternative to be able to buy products or services offered by the company. In the city of Semarang, there are more than 300 family businesses that are classified as longstanding, and the majority of them have not innovated much. The role of the owner in the organisation will be significant for the innovation process with the current conditions, through its interaction with an environment that is almost all influenced by technology.

The purpose of this study is to provide a broader and more in-depth view of the readiness of family businesses in the face of the era of digital disruption 4.0. There has not been much research conducted in Indonesia that raises family business as an object and examines industry readiness 4.0, with the method of Exploratory Factor Analysis (EFA).

\section{Hypothesis Development Family Business}

The family business is one of the unique research objects that have experienced exponential growth in recent years (Zellweger et al., 2010). The family business is defined as a business where management decisions are influenced by family relationships (Sharma et al., 1996). A family company is ownership, partnership, or a business form where control is in the hands of the family (Neubauer \& Lank, 1998). Some of these definitions can be interpreted that all decisions and control activities from planning to evaluation are in the hands of family members who are authorized to manage the business. Family business, about industry 4.0, has the challenge to keep the company going. Living dead companies with an increasingly fast-paced 
era now in the family members who manage the business. Decision making related to preparing all aspects for entry into industry 4.0. Will be a matter that needs to be considered by family members involved in it.

\section{Industry Readiness 4.0}

The first industrial revolution was spearheaded by the emergence of steam power and mechanization in the industry. The second revolution was caused by electricity production. The third industrial revolution is based on computers. Meanwhile, the fourth revolution today is also based on ICT but is associated with cyber-physical systems (Basl, 2017). The industrial world is marked by changes in the wave of technology that is fast and innovative (Alhajjar et al., 2018). The real impact that is happening now to the company, including products and services, which are flexibly connected online or application. Digital connectivity allows the production of goods and services that are automated and optimised automatically, including shipping, without human intervention (Maresova et al., 2018). Discussing the readiness of a business in the face of industry 4.0 will certainly directly discuss the preparedness of entrepreneurship itself.

Readiness for entrepreneurship which is determined by sociological, psychological, and business factors (Coduras et al, 2016). Readiness, in this case, does not mean to measure readiness to start a business but to see the readiness of the family business manager who has been running for a long time in the face of industrial changes 4.0. Individual readiness includes a series of items related to three important things, namely personal/family characteristics, economic background, and psychological.

The importance of the readiness of industrial 4.0 is related to many things including the process of enactment of the digital economy, which is a modern concept regarding changes in the industrial technology base, which will automate all operational, economic activities (Vasin et al., 2018). The family business is currently only partially applying to the transaction process in banking, not touching on the aspects of promotion, production and distribution. Industry 4.0 readiness can be measured by digital competencies that must be owned by the company including digital intelligence (digital intelligence) and technology, media and information skills (Information, Media And Technology Skills) (Wang \& Ha-brookshire, 2018).

The intended intelligence is the ability to interact with the environment. Successfully. Based on that ability or information that must be possessed by humans to have performance that is by the era of Industry 4.0 or can be interpreted as human interaction with the digital environment. Technological skills, media and information can be explained as skills in information literacy, media literacy and communication and for dealing with digital technology and media-driven situations. All of that is none other than one business goal, namely the sustainability and resilience of the business. Business continuity in the context of being able to meet market demand is relevant to its time.

\section{Competence and Strategy}

Competence can be said as critical behavior, knowledge, attitudes, abilities, values, practices, and related personal attributes in carrying out work, functions, and responsibilities (Bermúdez \& Juárez, 2017). It can also be said that knowledge, skills and attitudes must be able to be applied in productivity and produce useful results that contribute to the achievement of business goals. The characteristics of entrepreneurship itself is a behavioural adaptation goal to start, promote and maintain business activities and manage economic activities for the production and mobilisation of financial resources (Kurniawan and Yun, 2018). Entrepreneurial competence refers to the total ability to do work correctly which includes several attributes of an entrepreneur, such as social roles, character, motives, knowledge and skills. Such competencies are needed by business owners to solve real problems and to produce breakthroughs in the digital era. Of course, by doing some strategies that are rele- 
vant to the current conditions (Mamun et al., 2018). Therefore this research proposes the following hypothesis:

H1: There is a positive influence between entrepreneurial competencies on digital business strategies.

There are four things a family business can do by doing a digital business strategy. The four themes are (1) the scope of the strategy; (2) the scale of the strategy; (3) the speed of the strategy; (4) the source of business value creation (Bharadwaj et al., 2013). Strategies are essential to do if competencies are met and to facilitate the process of adjusting to industry 4.0. These four strategies indeed must be supported by the skills of each business by looking at individual aspects, business specialisation and business context. The strategy in the production line in Industry 4.0 is identified by a scale of production that is decentralised and digitalised which acts independently and can control operations efficiently in response to environmental changes and strategic objectives (Erol et al., 2016b). In the traditional family business, it is still constrained by the competence of the owner and the workforce. Therefore, the second hypotheses can be formulated as follows :

$\mathrm{H} 2$ : There is a positive influence between entrepreneurial capability on industry 4.0 readiness

Another much-needed competency is managerial competence, managerial competence is necessary because it can explain the skills and attitudes needed to face challenges in the future, and provide consistent and objective performance standards by creating what is needed and expected in the company (Veliu and Manxhari, 2017). Among the contents of managerial competencies are professional competence, social competence and personal. Family businesses tend to have all the contents of these competencies, but it needs to be proven whether they have been prepared to face this modern industrial era. Competitiveness is the primary goal of family companies to survive, in the short term, the quality and performance of the company's products determine the competitiveness of the company (Liu et al., 2017). Digitalization is one trend that is rapidly reshaping the global business environment (Wahlund \& Wåhlberg, 2018). In order to be able to survive and be ready in the digitalization era is to form a collaborative culture at all levels in an organization supported by business strategies.

H3: There is a positive influence between managerial competence on digital business strategies

$\mathrm{H} 4$ : There is a positive influence between managerial competence on industry 4.0 readiness

Many problems arise when business owners must adjust to current conditions that must modernise their business models. In previous studies focus on identifying competencies needed by the operational workforce in the face of industry 4.0, of course, supported by a digital business strategy is one thing that can encourage industry 4.0 readiness in addition to stability competence (Bermúdez \& Juárez, 2017). The importance of developing digital strategies as operational needs to ensure efficient and reliable processes and change operations using digital technology for more significant interaction and collaboration with customers (Sánchez, 2017). Reshaping the operating model requires the integration of all aspects of the business and optimizing everything related to the activity.

H5: There is a positive influence between digital business strategies on industry 4.0 readiness

\section{METHOD}

Exploratory Factor Analysis (EFA) method was used in this study (Nascimento \& Macedo, 2016), with path analysis model. Partial Least Squares (PLS) allow reflective calculations by measuring latent variables (Gudergan et al., 2008). A total of 93 family business units were taken to be used as samples and using a 5-point Likert scale. Analysis and measurement 
techniques use (1) outer model/measurement model); and (2) inner model / structural model (Hair et al., 2014) assisted by SMART-PLS software. When estimating the model, it is necessary to simultaneously take into account the measurements and structural components as well (Anderson \& Swaminathan, 2011).

\section{RESULT AND DISCUSSION}

Results of the study are shown in Figure.1, which is a model of the results of the analysis using SMART PLS. For the results to be reli- means it is at an excellent level. Average Variance Extracted (AVE) is in the range 0.517-0.603, whose value is $>0.50$ indicates that the average indicator can explain the construct. Discriminant Validity, which demonstrates that the indicator on cross-loading of business strategy extracts (BST13-BST19) is higher than loading factors in other constructs. Based on the results of reflective measurement evaluation, it can be said that the validity and reliability of the indicators are directly connected to the construct. From these results, it can be continued to evaluate the structural model.

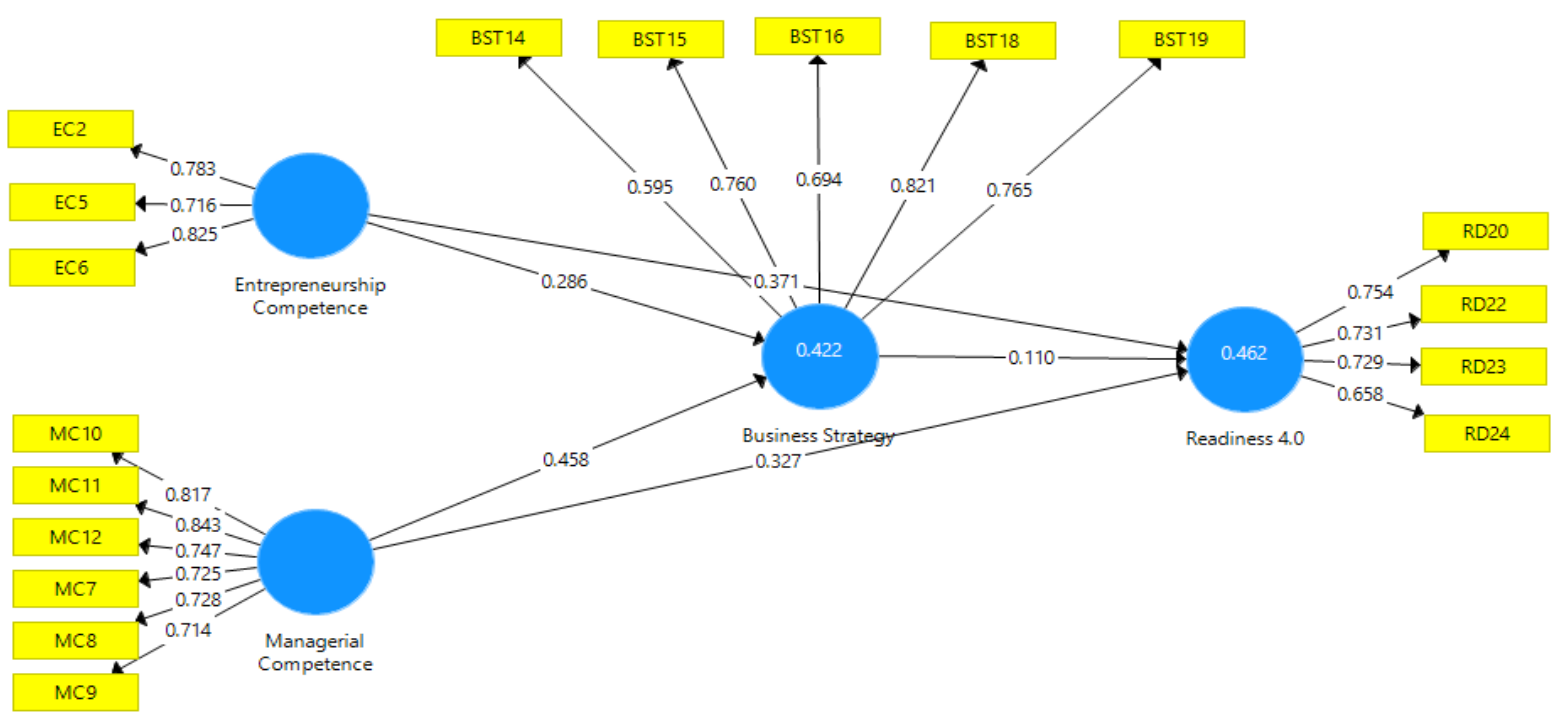

Figure 1. Readiness Model 4.0

able, we need to calculate the reliability shown in Table 1, where Cronbach's alpha produces a value of $0.670-0.858$, which indicates that it has right enough consistency. While the Composite Reliability is in the range of 0.810-0.893, which
Evaluation of structure models is intended to measure predictors and relationships between constructs (Hair et al., 2014). The first step is by assessing colinearity, by looking at VIF in the range 1.328-1.729 < 5. Testing of path

Table 1. Assessment of the Measurement Model

\begin{tabular}{lccc}
\hline \multicolumn{1}{c}{ Construct } & $\begin{array}{c}\text { Cronbach's } \\
\text { Alpha }\end{array}$ & $\begin{array}{c}\text { Composite } \\
\text { Reliability }\end{array}$ & $\begin{array}{c}\text { Average Variance } \\
\text { Extracted (AVE) }\end{array}$ \\
\hline Business Strategy & 0.779 & 0.850 & 0.535 \\
Entrepreneurship Competence & 0.670 & 0.819 & 0.603 \\
Managerial Competence & 0.858 & 0.893 & 0.583 \\
Readiness 4.0 & 0.691 & 0.810 & 0.517 \\
\hline
\end{tabular}


coefficients is explained in Table 2 , has a positive value $(+1)$, which means it has a positive and significant relationship at the significance level of 1.96 (5\%). The coefficient of determination (R2) in the Table 3, shows the value of 0.4217 in business strategy and 0.4620 in readiness. With a value that is between $0-1$, it can be said that the prediction accuracy of the model is at the middle level (moderate), the value represents the combined effect of exogenous variables on endogenous variables. Next $\mathfrak{f} 2$ to see the magnitude of the effect of exogenous variables, the values are classified as having intermediate level effects shown in Table 2. The next step is Predictive Relevance Q2 in Table 3, this test is useful for evaluating the level of predictive accuracy. Using a blindfolding procedure, it is known that Q2 (0.196-0.197) indicates that exogenous extracts have predictive relevance at a moderate level for endogenous constructs. automated. Knowledge and skills in adapting to technology need to be owned by every member of the family business. The process of promotion, production, and maintaining business with technological interference. The attitude emphasised here is in the actions of business owners when dealing with new technologies that threaten their business. The right attitude is to decide on the actions taken to minimise the threat. For example, the promotion process has used a lot of web and marketplace, but many family businesses have not implemented the strategy to use the technology. They are still constrained by adequate human resources to manage, and the decision of business owners not to use this method. They choose the attitude not to apply automation to all components of their business because they consider the workforce they have.

Entrepreneurship competency will illustrate that a family business is said to be ready

Table 2. Assessment of the Structural Model (path coefficients \& f2)

\begin{tabular}{lll}
\hline & path coefficients & f2 \\
\hline Business Strategy => Readiness 4.0 & 0.110 & 0.013 \\
Entrepreneurship Competence=>Business Strategy & 0.286 & 0.107 \\
Entrepreneurship Competence=>Readiness 4.0 & 0.371 & 0.174 \\
Managerial Competence=>Business Strategy & 0.458 & 0.273 \\
Managerial Competence=>Readiness 4.0 & 0.327 & 0.117 \\
\hline
\end{tabular}

Table 3. Assessment of the Structural Model (R2 \& Q2)

\begin{tabular}{lcc}
\hline & Coefficient of Determination(R2) & Q2(=1-SSE/SSO) \\
\hline $\begin{array}{l}\text { Business Strategy } \\
\begin{array}{l}\text { Entrepreneurship } \\
\text { Competence }\end{array}\end{array}$ & 0.422 & 0.196 \\
$\begin{array}{l}\text { Managerial Competence } \\
\text { Readiness 4.0 }\end{array}$ & & \\
\hline
\end{tabular}

Based on structural test results and measurement models, it shows that hypothesis 1 and 2 are acceptable and significant, as shown in Table 2, this result is indeed able to provide predictions that entrepreneurial competence with a measure of knowledge, skills and attitudes to deal with and adapt to industry 4.0 are all fully to enter the industrial 4.0 era by implementing several strategies, namely business scope, strategy scale, the speed of strategy, and source of business value creation (Bharadwaj et al., 2013). Scope, in this case, the family business must be able to define products and businesses and activities carried out in direct control by the owner 
on the application of digital technology in his business unit. The scale of strategy is a driving factor for business profitability; this refers to business infrastructure, which certainly does not refer to physical production and supply chains that seem to be conventional. However, more emphasis on physical, digital things to support more efficient information circulation. Speed here refers to the speed of launching or new products or services offered by the family business by utilising digital networks, for example, social media and the web. The speed of decision making is also needed in the era of information and transaction turnaround. The role of business owners is the key to being able to make decisions regarding meeting the needs of consumers and fulfilling supplier offers. In the end, entrepreneurial competence is directly able to become an appropriate predictor to prepare a family business in the face of industry 4.0. Whereas if competency is equipped with the right business strategy, then the family business is indirectly able to create its way to adapt.

Hypothesis 3 and hypothesis 4 also have positive and significant influences. Managerial competencies have path coefficients that are quite high compared to other predictors. This is known from managerial competency indicators, namely professional, social and personal. In hypothesis 3 , it is known that managerial competencies have a fair share in the realisation of business strategies. Professional, which is one indicator of managerial competence has the connection that in planning, problem-solving, information gathering, analytical thinking, communication and cooperation are things that need to be owned by every family member who participates in managing the business directly. This is much related to the ability to implement the strategy used by looking at conformity with business characteristics. So not all family members can have the expected managerial abilities, but of course, if they enter the business environment, they must master so that they can be said to be ready for the fast-paced industry 4.0. Hypothesis 5 also has a positive and significant influence between business strategies on industry 4.0 readiness.
Industry 4.0 readiness is closely related to information and communication technology (ICT) so that family business that still applies a lot of conventional business models must be able to adapt their respective strategies to suit to several things that will be faced. Such as information and communication technology, in this is the presence of the internet as a matter that is considered as a primary need that supports almost all processes of business running. Manufacturing and automation technology that prioritizes the all-automatic production and distribution process with almost perfect and efficient results. The changing era that prioritises technology certainly has an impact on the workforce component, but that is a reality that must be faced by all businesses, especially family businesses that prioritise relationships that are close to all of their workforce.

\section{CONCLUSIONAND RECOMMENDATION}

Based on the results and discussion it shows that entrepreneurial competence and managerial competence in the family business have a positive and significant influence on industry readiness 4.0. Competence especially in the implementation of managerial competencies for business owners. Indirectly, family businesses can implement business strategies that are in accordance with the characteristics of their business by utilizing all digital-based operational fields, of course, supported also by qualified human resources, so that they can adapt to rapidly changing conditions. It is hoped that this finding can be used as a reference for family business units in the city of Semarang to prepare for industry 4.0. Future research is expected to explore the impact of competencies that are not ready for change in industry 4.0.

\section{REFERENCES}

Alhajjar, A. A., Kassim, R. M., Raju, V., \& Alnachef, T. (2018). Driving Industry 4. 0 Business through Talent Management Of Human Resource System: the Con- 
Aryan Eka Prastya Nugraha et al./ Analysis Of Industrial Readiness 4.0 On Family Business In Semarang City

ceptual Framework for Banking Industry. World Journal of Research And Review (WJRR), 7(3), 53-57.

Al Mamun, A., Muniady, R. A. L., Ibrahim, M. A. H. B., \& Nawi, N. B. C. (2018). Effect of economic vulnerability on entrepreneurial competencies among Malaysian micro-entrepreneurs. Asia Pacific Journal of Innovation and Entrepreneurship, 12(2), 222-237.

Al Mamun, A., Subramaniam, E., Che Nawi, N. and Zainol, N. (2016), Entrepreneurial competencies and performance of informal micro-enterprises in Malaysia. Mediterranean Journal of Social Sciences, 7(3), 273-28.

Anderson, R. E., \& Swaminathan, S., (2011). Customer Satisfaction and Loyalty in EMarkets: a PLS Path Modeling Approach. The Journal of Marketing Theory and Practice, 19(2), 221-234.

Basl, J. (2016). The Pilot Survey of the Industry 4.0 Principles Penetration in the Selected Czech and Polish Companies. Journal of Systems Integration, 7(4), 3.

Basl,J. (2017). Pilot Study of Readiness of Czech Companies to Implement the Principles of Industry 4.0. Management and Production Engineering Review, 8(2), 3-8.

Bermúdez, M. D., \& Juárez, B. F. (2017). Competencies to Adopt Industry 4. 0 for Operations Management Personnel at Automotive Parts Suppliers In. In Proceedings of The International Conference On Industrial Engineering And Operations Management (Pp. 736-747).

Bharadwaj, A., El Sawy, O. A., Pavlou, P. A., \& Venkatraman, N. (2013). Digital Business Strategy: toward a Next Generation of Insights. MIS Quarterly, 37(2), 471-482.

Coduras, A., Saiz-Alvarez, J. M., \& Ruiz, J. (2016). Journal of Innovation Conceptual Paper Measuring Readiness For Entrepreneurship: an Information Tool Proposal. Suma De Negocios, 1-10.

Erol, S., Jäger, A., Hold, P., Ott, K., \& Sihn, W. (2016a). Tangible Industry 4.0: a Scenar-
io-Based Approach to Learning for the Future of Production. Procedia CIRP, 54, 13-18.

Erol, S., Jäger, A., Hold, P., Ott, K., \& Sihn, W. (2016b). Tangible Industry 4.0: a Scenario-Based Approach to Learning for The Future of Production. In 6th CIRP Conference on Learning Factories Tangible, 54, 13-18. Elsevier B.V.

Gabriel, M., \& Pessl, E. (2016). Industry 4.0 and Sustainability Impacts: critical discussion of sustainability aspects with a special focus on future of work and ecological consequences. Annals of the Faculty of Engineering Hunedoara, 14(2), 131.

Gjerding, A. N., \& Kringelum, L. B. (2018). Sustainable Business Models: Contribution for the Circular Economy. In 2nd Business Model Conference (P. 8).

Gudergan, S. P., Ringle, C. M., Wende, S., \& Will, A. (2008). Confirmatory Tetrad Analysis In PLS Path Modeling. Journal of Business Research, 61(12), 1238-1249.

Hair, J. F., Sarstedt, M., Hopkins, L., \& Kuppelwieser, V. G. (2014). Partial Least Squares Structural Equation Modeling (PLS-SEM) an Emerging Tool In Business Research. European Business Review, 26, 106-121.

Kurniawan, A., \& Yun, Y. U. N. (2019). Relationship Between Business Competence and Business Survival of Culinary Business in Bandung. MIMBAR, 34(1), 147157.

Liu, J., Lu, H., \& Li, X. (2017). On the Core Competence of Enterprises. Business Administration And Management, 1, 1-7.

Man, T., \& Lau, T. (2000), Entrepreneurial competencies of SME owner/managers in the Hong Kong services sector: a qualitative analysis. Journal of Enterprising Culture, 8(3), 235-254.

Maresova, P., Soukal, I., Svobodova, L., Hedvicakova, M., Javanmardi, E., Selamat, A., \& Krejcar, O. (2018). Consequences of Industry 4.0 in Business and Economics. Economies, 6(3), 46. 
Nascimento, J. C. H. B. Do, \& Macedo, M. A. Da S. (2016). Structural Equation Models Using Partial Least Squares: an Example of the Application of Smartpls In Accounting Research. Journal Of Education and Research in Accounting Revista de Educação e Pesquisa em Contabilidade, 10(3), 282-305.

Neubauer, F., \& Lank, A. G. (1998). The Family Business its Governance for Sustainability.

Rojko, A. (2017). Industry 4 . 0 Concept: Background and Overview. Journal of Interactive Mobile Technologies, 11(5), 77-90.

Sánchez, M. A. (2017). A framework to assess organizational readiness for the digital transformation. Dimensión Empresarial, 15(2), 27-40.

Sharma, P., Chrisman, J.J., \& Chua, J. H. (1996). A Review and Annotated Bibliography of Family Business Studies. Kluwer Academic Publishers.

Vasin, S., Gamidullaeva, L., Shkarupeta, E., Palatkin, I., \& Vasina, T. (2018). Emerging Trends and Opportunities for Industry 4 . 0 Development in Russia. European Research Studies Journal, XXI(3), 63-76.
Veliu, L., \& Manxhari, M. (2017). Social Sciences the Impact of Managerial Competencies on Business Performance: SME' $S$ in Kosovo. Vadyba Journal Of Management, 30(1), 59-65.

Wahlund, F., \& Wåhlberg, V. (2018). Digitalization \& Competence Management a study of digitalization and competence management within the telecommunications industry. Thesis. Chalmers University of Technology

Wang, B., \& Ha-brookshire, J. E. (2018). Exploration of Digital Competency Requirements within the Fashion Supply Chain with an Anticipation of Industry 4.0 Exploration of Digital Competency Requirements within the Fashion Supply Chain with an Anticipation of Industry 4.0. International Journal of Fashion Design, Technology and Education, 11(3), 333-342.

Zellweger, T. M., Eddleston, K. A., \& Kellermanns, F. W. (2010). Exploring the Concept of Familiness: Introducing Family Firm Identity. Journal of Family Business Strategy, 1(1), 54-63. 